HStud 25 (2011)2, 315-328

DOI: 10.1556/HStud.25.2011.2.11

\title{
THE HUNGARIAN RECEPTION OF GEORGE ELIOT IN HUNGARY
}

\author{
MIHÁLY SZEGEDY-MASZÁK \\ Eötvös Loránd University \\ Budapest, Hungary
}

\begin{abstract}
The reception of the works of George Eliot in Hungary offers an interesting perspective from which to rethink some of the fundamental questions of reception theory and the interrelationships between political and social contexts and attitudes towards works of literature. Furthermore, shifting responses to Eliot illustrate the significance of divergences in approach to translation in the canonization of a work of literature in another literary tradition.
\end{abstract}

Keywords: George Eliot, reception theory, translation, literature, appropriation, canonization, Hungary

It is a curious fact that sometimes the authors of reception studies have a tendency to imply that the popularity of literary works is relatively independent of political changes. They seldom spare a word for historical circumstances. Here, however, I shall take the liberty of defying that convention.

Sometimes the reception of works written in English precedes the translation of these works in countries in which English is not the most common or national language. Following the lead of Count István Széchenyi (1791-1860), who fought as a soldier in the war against Napoleon, visited Britain on a regular basis from 1815 on, and collected books in English, numerous Hungarian aristocrats and prominent members of the upper middle class regarded England as a model for the civilized world. When Bernhard Tauchnitz (1816-95), the owner of a printing and publishing firm, started his Collection of British and American Authors in Leipzig in 1841, this reprint series made English novels available to Hungarian readers in inexpensive editions. British (and to a lesser extent North American) literature became fashionable in upper middle class urban families that put particular emphasis on reading not only in German but also in English and French. The relatively high number of copies of Tauchnitz publications that survive in public collections (for example in the Library of the Hungarian Academy of Sciences) and private libraries would suggest that the bourgeoisie of the rapidly de- 
veloping capital was eager to read contemporary British fiction. The example of Géza Barkassy (1849-1922), the son of a Hungarian lawyer of noble origin and the daughter of a wealthy German entrepreneur, may indicate that reading George Eliot in the original was not limited to men of letters. Having studied law at the University of Vienna (leveltar.elte.hu/databases.php?ekod=1), he became a civil servant who by the end of the century was raised to the high rank of a ministerial adviser and one of the organizers of the world exhibition held in Budapest in 1896. As a bachelor with a high salary, he could afford to assemble an extensive library. He systematically ordered the volumes of the Tauchnitz collection. His nephews and nieces constantly used his library; this meant five to ten potential readers in the case of most of his books.

The list of the works sent from Leipzig to Hungarian libraries and individuals is as follows: Scenes of Clerical Life (vols. 462-463, 1859), Adam Bede (vols. 482-483, 1859), The Mill on the Floss (vols. 509-510, 1860), Silas Marner (vol. 550, 1861), Romola (vols. 682-683), Daniel Deronda (vols. 1617-1620, 1876), The Lifted Veil and Brother Jacob (vol. 1732, 1878), Impressions of Theophrastus Such (vol. 1828, 1879), Essays and Leaves from a Note-Book (vol. 2229, 1884), and George Eliot's Life as Related in the Letters and Journals (vols. 2318-2321, 1885). Copies of these volumes still exist with notes made by contemporary readers. In view of the fact that much of Géza Barkassy's library was destroyed after World War II (when some members of his family were deported to labour camps as "class aliens"), it cannot be taken for granted that he read them all. Still, since all the books of his that have survived (among them several multi-volume works) contain his notes, it can be assumed that he may have read most of them. The internet records his support of Hungarian publishers (www.friweb.hu/iratok/ tudomány/PART1895.htm) and the surviving part of his library reveals that he was eager to read the translations of works known to him in the original. Copies of the first Hungarian versions of Adam Bede, Silas Marner, and Middlemarch still exist.

After the Compromise of 1867 between the Habsburg dynasty and the Hungarian political leaders, Liberalism stamped Hungarian culture, and Darwinism made its influence felt, especially among the prominent members of the Protestant intelligentsia. Both paved the way for the early reception of the works of George Eliot. The first translation of Adam Bede was done by a friend of Géza Barkassy, the Transylvanian Ferenc Salamon (1825-92), and published in 1861-62. It was due to the high prestige of George Eliot that the Hungarian version of her first major novel was done by a distinguished historian and literary critic, who by 1859 was elected to the Hungarian Academy of Sciences as a corresponding (and in 1871 as a full) member, and in 1870 was given a chair at the University of Budapest. His translation proved to be of lasting value; in 1888 it was republished in a highly popular series edited by Pál Gyulai (1826-1909), poet, short-story writer, and 
critic, another member of the Academy and one of the most influential Hungarian authors of the period.

In the 1860 s the rules of domestication or naturalization were different from the principles of appropriation followed in the later 20th century. Numerous proper names were translated by Salamon. Molly has become Máli, Hetty was rendered as Eszti. It would be unjust to dismiss this practice as a whole. George Eliot's first Hungarian translator seemed to be fully aware that the distinction between proper and class nouns was open to question. In the chapter entitled "The Games" the nickname of Wiry Ben became "Dorót Bence" (Eliot, 1888, 1: 415). In the translation done more than a century later the character is called Ben (Eliot 1978, 321). Without exaggeration it could be argued that the heterogeneity of the language of the novel is more perceptible in the first translation than in the version published more than a century later.

In many cases Salamon proved to be a creative interpreter. In chapter 53, entitled "The Harvest Supper", Kester Bale is mentioned as one of the labourers of Martin Poyser. In the Hungarian text this old man is called Bordás Péter (Eliot, 1888, 2: 370). His surname refers to "the network of wrinkles on his sun-browned face". In chapter 24, after the twenty-one-year-old Captain Arthur Donnithorne has proposed his grandfather's health, Mrs. Poyser makes the following remark: "he'd better not ha' stirred a kettle o' sour broth". Salamon has succeeded in finding a proverbial expression in the target language: "jobb lett volna föl nem keverni azt a romlott tejes bögrét” (Eliot, 1888, 1: 396).

Appropriation may involve not only replacement but also addition. Occasionally small changes were necessary for the sake of clarification. At some stage in "The Harvest Supper" the conversation takes a political turn. Mr. Poyser calls the French wicked and Mr. Craig insists that he is "in no fear o' Bony, for all they talk so much o' his cliverness". In the Hungarian version Bonaparte is mentioned (Eliot, 1888, 2: 375). The lower-class characters of Adam Bede do not speak standard English. The incorrect usage is missing in Salamon's text. He reduced the dialectal components of the English novel, but introduced some adjectives with the aim of distinguishing the language of the lower classes from the discourse of the landowners. "Why, Hetty, lass, are ye turned Methodist?" says Mr. Poyser to Miss Sorrel. Salamon adds an almost proverbial expression: "Lánchordta leánya, bizony methodista lett" (Eliot, 1888, 1:336). In some respects his translation is almost more nuanced than the source text. Repetitions are fewer. At the end of the above-mentioned chapter 24 , in the description of the health drinking at the celebration of Arthur Donnithorne's twenty-first birthday, the hero merely bows to Hetty. "The foolish child felt her heart swelling with discontent". In the Hungarian version she is called "együgyü" (Eliot, 1888, 1: 404), a word with multiple meanings, ranging from "focused on a single issue" and "self-centred" to "simple-minded", and "naive". The immediate context confirms that Salamon's inter- 
pretation is based on a careful reading of the novel. His adjective suggests that the seventeen-year-old girl lives in a world of illusions.

Omissions may shed even more light on the difference between the source and the target cultures. Some of these concern details of no great significance. In chapter 19 ("Adam on a Working Day"), no distinction is made between "ale" and "beer", since the Hungarian language has but one word ("sör"). Far more important is that the first Hungarian translation of Adam Bede does not contain chapter 17. The title of this section is "In Which the Story Pauses a Little". Ferenc Salamon was one of the first interpreters of the fiction of Zsigmond Kemény (1814-75), another Transylvanian Protestant. At the time he was translating Adam Bede, in 1861-62, he published a significant essay on the last novel of this author in the periodical Szépirodalmi Figyelö, edited by János Arany, the most important Hungarian poet of the second half of the 19th century. In addition to being an outstanding novelist, Kemény was also a highly original theoretician. In Eszmék a regény és dráma körül (Ideas on Drama and the Novel, 1852), originally published in installments, he predicted an increasing objectivity in narrative fiction. Salamon, himself a fine essayist, valued Kemény's attempt to create an autonomous fictional world. It can be assumed that he decided to translate Adam Bede because he saw some parallel between this English novel and Kemény's fictional world. He might have seen fundamental similarities between the British author's first full-length novel and A rajongók (The Fanatics), a work Kemény published in 1858-59. Both novels quote the preaching of a religious visionary at the outset, deal with predestination, and highlight the interior world of the characters. The most conspicuous difference between the two works is the narrator's frequent addressing the reader in the English text. In The Fanatics the characters seem to be independent of the story-teller's discourse. Following his master, Salamon regarded this relative autonomy as a distinguishing feature of narrative as a sophisticated form of art, liberated from the legacy of popular fiction. While he could not suppress the constant intrusion of the story-teller's voice in Adam Bede, he eliminated the chapter that seemed purely essayistic. Whether he was justified in doing so, he undoubtedly identified a characteristic component of George Eliot's fiction. The use of the first person singular and plural gave considerable opportunity to make general statements and tended to blur the distinction between the world of the novel and that of the narrator and the narratee. The narrator's strong involvement in the fate of the characters was at odds with Salamon's ideal of the novel based on his reading of Kemény's narrative fiction. The reason for the omission of an entire chapter was his dislike of overinterpretation.

A far less substantial omission can be found at the end of chapter 52 ("Adam and Dinah"). The narrator is addressing a personified abstraction (Leisure). The final words state that "he never went to Exeter Hall, or heard a popular preacher, or read Tracts for the Times or Sartor Resartus". The Hungarian version excludes 
the specific reference to the two texts. Since Carlyle's work was well-known to some Hungarians, it is likely that the reason for this omission was that the translator believed that intertextual allusions were out of place in a tale about provincial life. In chapter 38 ("The Quest") Seth Bede recites two stanzas of one of his favourite hymns. They are omitted by Salamon. In a similar way, when Dinah sings one of Charles Wesley's hymns in chapter 50 ("In the Cottage"), or a drinking song is cited in "The Harvest Supper", the verses cannot be found in the Hungarian text. Yet it would be incorrect to conclude that Salamon left out all the verses. In the opening chapter the text of the song sung by the title hero is quoted twice, in accordance with the source text. The most probable explanation is that in this case verse is used as a mode of characterization. In the other cases the translator may have regarded the citations as less functional. All in all, he tried to eliminate the markers of the narrator's presence. That is why he left out the adjective when the Poysters' housemaid is called "poor Molly", and skipped a whole chapter in a translation that must be called very successful.

The high quality of Salamon's work becomes quite obvious in comparison with the rather careless translation of Felix Holt, by Mária Dominkovics, whose only other work known to me is a collection of short stories published in two volumes in 1867. More important is the first Hungarian version of Middlemarch, published in four volumes in 1874-75. Its translator was an assimilated Jew who changed his original surname Hechtl to Csukássi. Having studied law in Vienna and Pest, József Csukássi (1841-91) was active as journalist, published verse, short stories, and articles, and translated works by Burns, Hugo, George Sand, Tennyson, Mrs. Gaskell, Wilkie Collins, and others.

Since the first translations of Adam Bede and Middlemarch were published by the Kisfaludy Society, founded in 1837, its members got them free of charge. That meant about four hundred potential readers (Pallas, 1895, 593). Unlike Adam Bede, Middlemarch was published for an educated public. Accordingly, the inscriptions in Italian and French were not translated. Géza Barkassy, for instance, whose copy (in 1892 given to her niece Cécile Tormay, who later became a successful novelist and short-story writer) has survived, read not only Chaucer, Ben Jonson, Locke, and Gibbon, but also Dante, Goethe, and Musset in the original.

Some of the norms of translation had changed between the early 1860s and the mid-70s. English Christian names were no longer replaced by Hungarian ones. Most of the characters of Middlemarch belong to the middle class. Mr. Dagley is an exception. His son Jacob has been caught killing a leveret. At the end of chapter $39 \mathrm{Mr}$. Brooke, Dorothea's uncle, tells Dagley that the young boy has been locked up in an empty stable. The father answers him using harsh words. Dagney's English is substandard. Such class distinctions can be rarely perceived in the language of the Hungarian version. Still, there are a few exceptions. In chapter 24, for instance, Mrs. Garth is teaching correct pronunciation. One of her students mocks 
those who say "A ship's in the garden". In the Hungarian text people who use "kő" instead of "kell" are ridiculed (Eliot, 1874-75, 2: 32).

In the 19th century Hungarian translators paid scarce attention to the signifier. In chapter 86 there is a pun. "It will be a sad while before you can be married, Mary", says Mr. Garth to his daughter. The girl's witty response is as follows: "Not a sad while, father - I mean to be merry". The link between the three words: the adjective "merry", the verb "marry", and the Christian name "Mary" has no equivalent in the translation.

Csukássi's translation has a short introduction by Ágost Greguss (1825-82), a celebrated essayist who aside from translating works ranging from Measure for Measure, Timon of Athens, and Cid to works by Jean-Jacques Rousseau, Schiller, and Georges Sand, wrote theoretical works on aesthetics and a monograph on the ballad that is still considered a standard work by specialists of both literature and folklore. In his two-page-long text Greguss states that the translation has been corrected by Arthur Patterson and Ágost Pulszky (1846-1901), a sociologist and philosopher who studied in England. One cannot help but conclude that the first translation of George Eliot's most important work had been carefully prepared. In addition, it may have drawn attention to some authors unknown in Hungary. It was thanks to the chapter headings of this novel that the first Hungarian translations of poems by "Dr. Donne", Samuel Daniel, and Sir Henry Wotton appeared.

The fact that Middlemarch was published separately and not as part of the inexpensive series mentioned above may suggest that unlike Adam Bede, it was thought to be for a more limited readership. If we turn to the first Hungarian version of Silas Marner, we find our surmise confirmed. Published in the popular series edited by Pál Gyulai in 1885, it had a second impression in 1898. The translator Géza Kacziány (1856-1939) was a prolific journalist specializing in music and the visual arts, as well as the author of short stories, plays, and poems. Like Salamon, he was attracted to the works of George Eliot because of his Protestantism. First he taught in the main secondary school of the Reformed Church in Budapest, in 1903-04 he traveled in Britain and the United States, and in 1909-12 he served as the Presbyterian clergyman of the Americans of Hungarian origin. His translation of The Corsair and his German versions of 130 poems of Petófi attest to his interest in verse, and his translation of Silas Marner suggests that he regarded this work as a poem in prose.

No less prestigious was the first translator of The Mill on the Floss, published in the same inexpensive series in 1897. Unfortunately, this has to be called a somewhat pedestrian version. János Váczy (1859-1918) was the author of literary biographies and the scholarly editor of important literary works. He saw George Eliot through the eyes of a Positivist. In sharp contrast to Salamon, he looked for the impact of contemporary science and the ideas of George Henry Lewes in her works. The Mill on the Floss was the only novel he ever translated. His version is 
no more than a historical document, together with Béla Pataki's version of Romola, published with the support of the Kisfaludy Society, one year later.

One of the signs of George Eliot's high reputation in Hungary in the late 19th century was that her works were cited even in reviews of narrative fiction written by Hungarian authors. A prime example is the discussion of short stories by the minor author Sándor Baksay, in an article published in 1887 by Jenő Péterfy (1850-99), by far the most original Hungarian critic of the period. The inferior quality of the short stories is analyzed in comparison with the British author's approach to her world. While Baksay's narrator is part of the provincial life he presents, George Eliot's "horizon is wider than that of her characters" ("láthatára messzebb terjed, mint alakjaié") (Péterfy, 1903, 424). The critic does not deny the melodramatic element in George Eliot's narratives, but he suggests that it is the mark of a more refined art that in her works "harm is not done by evil but by narrow-mindedness, dullness, provincialism when confronted with more sophisticated things and human beings" ("nem a fekete gonosz okozza a legföbb bajt az életben, hanem a korlátoltság, butaság, köznapiság, mikor olyan dolgokkal s emberekkel kerül össze, kik fölötte állanak”) (Péterfy, 1903, 426).

A well-trained critic not only of literary but also of musical works, Péterfy advocated a theory of the tragic (not the genre but the aesthetic quality) based on a theory of value. In his view the tragic was an immanent quality of human existence incompatible with moral justice. Because of this, he regarded the art of Kemény and Flaubert as superior to that of George Eliot, whom he viewed as a novelist who overemphasized moral values. Salamon's work as translator and Péterfy's criticism represented a position similar to that of Henry James, expressed in his review of The Life of George Eliot, written by her husband J. W. Cross. Both Hungarians appreciated the fiction of the British woman writer, but preferred novels with a more objective narrative perspective, in a manner similar to James, who in 1885 argued as follows:

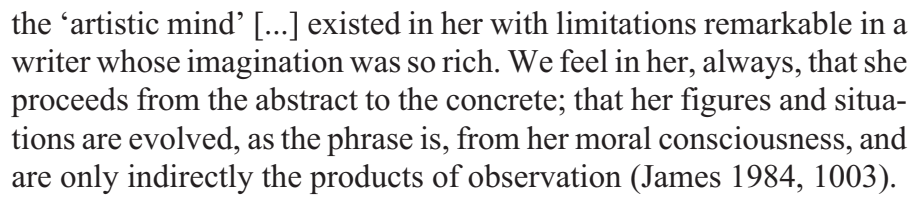

Despite the reservations of Salamon and Péterfy, George Eliot was one of the most celebrated British authors in Hungary at the end of the 19th century. This is clear from the 64-line article in the most important encyclopaedia, published in eighteen volumes between 1893 and 1900 (Pallas, 1894, 40). Its author, Gyula Theisz (1855-1939), a literary historian and translator of German origin born in the northern region known as Zips, focused on Adam Bede, The Mill on the Floss, Silas Marner, Romola, Felix Holt, and Middlemarch, but in the spirit of Positiv- 
ism, he also mentioned the translation of Das Leben Jesu, Scenes of Clerical Life, and Daniel Deronda, and even the most memorable poems. The objectivity of the approach is further strengthened by reliable biographical and bibliographical data. An article in an encyclopaedia is not expected to aspire to originality. All the major works are mentioned. Although a bit too much emphasis is placed on Romola, the cautious value judgments are justifiable, especially in view of the quality of the translations: Adam Bede is called a masterpiece and the significance of Middlemarch is duly recognized.

After 1900 the lustre of George Eliot seemed diminished. For more than half a century no new translations were completed. First the crude social determinism of the Naturalists, and somewhat later the aesthetic movement made her fiction unfashionable. The influence of the latter can be detected in Az európai irodalom története (A History of European Literature) by Mihály Babits (1883-1941), poet, novelist, short-story writer, essayist, and translator, one of the most respected figures in the literature of the period. The passage on George Eliot in what was originally published as volume 2 of his highly personal outline history in 1935 is clearly based on the early translations: "I read some of her works when I was a student and was surprised to learn that their author was a woman. [...] Eliot's world is dark and almost mechanically tragic. Individual lives are destroyed by petty weaknesses. Regrettably, this sense of life led to the education of the world [...]. Far from being an apostle, she was a school teacher. Since she was eager to instruct, she also published historical novels." ("Én diákkoromban olvastam néhány könyvét, s meglepetés volt, hogy ezeket nő írta. [...] De nem apostol volt ő, inkább csak tanító néni. Leckéi érdekében történeti regényeket is írt") (Babits, n. d., 603-4). Adam Bede is the only novel mentioned, probably because Babits respected Salamon. When he drafted a plan of an anthology of European literature, he included a section of Adam Bede in the translation first published in 1861-62 (Babits, 1978, 221). The error in the last sentence quoted suggests that he relied on his vague memories; in his later years he did not read anything by George Eliot.

International projects are easy targets for those who look for oversights. The series entitled The Reception of British and Irish Authors in Europe has an excellent volume on Virginia Woolf that includes no chapter on the reception of her works in Hungary. Because of this, I have to make a digression. One of the reasons for the decline in George Eliot's reputation was the (mistaken) belief that the activity of the so-called Georgian women writers made the Victorian George Eliot fade into oblivion. Antal Szerb (1901-45), who in many respects accepted the approach to literature represented by Babits, died in a labour camp. When assessing his activity, it is virtually impossible not to remember his tragic end. In 1935 he published a book entitled Hétköznapok és csodák (Weekdays and Wonders). The title may have been inspired by a reading of Lady into Fox and Orlando. 
The main thesis of this book is based on a comparison of Victorian values and the outlook of such writers as Virginia Woolf, Rose Macaulay, Rebecca West, Sylvia Townshend Warner, and others. Much emphasis is placed on the fact that George Sand and George Eliot used masculine pen names. "Their novels are similar to those written by men; they had masculine features. Their intention was to look at the world in the way men saw it" "'A regényeik is olyanok, mintha férfiak írták volna őket, aminthogy egyéniségükben is sok volt a férfias vonás. Írásaikban arra törekedtek, hogy úgy lássák a világot, mint a férfiak látják”) (Szerb, 1971, 559). With his usual disregard for details, Szerb ignored the fact that Virginia Woolf highly estimated George Eliot. His somewhat one-sided approach was probably inspired by Virginia Woolf's attack on Bennett, Wells, and Galsworthy and by Rose Macaulay's Told by an Idiot (1923), which has four sections entitled "Victorian", "Fin-de-siècle", "Edwardian", and "Georgian".

Szerb persisted in his partially negative attitude towards George Eliot when writing his $A$ világirodalom története (A History of World Literature), first published in 1941. The single paragraph on this author is based on three comparisons. "The reputation of the Brontës never declined since their deaths; their works went into numerous editions, even Emily's poems became widely appreciated. Travellers often visit Haworth, where they lived as hermits. By contrast, the once immense popularity of George Eliot (Mary Ann Evans, 1819-80) seems to have evaporated." (“A Brontë nővérek írói hírneve nem csökkent haláluk után; műveik egyre újabb kiadásokban jelentek meg, gyönyörúséggel olvassuk Emily költeményeit is, és Haworthot, remeteségük színhelyét sürün látogatják az áhítatos kirándulók; fiatalabb kortársnőjük, George Eliot (May Ann Evans, 1819-80) egykor óriási népszerüsége enyészőben van.”) (Szerb, 1980, 558). The second comparison is with Dickens and Thackeray. Szerb admits that in contrast to these two novelists, Georg Eliot was an intellectual with a warehouse of knowledge and someone who took a serious interest in Darwinism, the rise of science, and the crisis of religious faith. The last parallel is drawn with Zola, revealing the decisive influence Babits exerted on Szerb. Positivism is mentioned as George Eliot's main source of inspiration and her works are interpreted as representing a realism that verges on naturalism. The Mill on the Floss and Middlemarch are characterized as her most significant achievements. The former is appreciated for its treatment of the status of woman in Victorian society, the latter for its portrayal of the life of the bourgeoisie. "Her meditations are rather strenuous" ("Elmélkedései eléggé fárasztóak") (Szerb, 1980, 559). This conclusion indicates that by the middle of the 20th century didacticism became regarded as a burden incompatible with the art of the novel.

As is well-known, a radical change occurred in the approach to literature in the European countries occupied by the troops of the Soviet Union in 1945. During the subsequent decades György Lukács was regarded as the greatest authority in 
literary studies. In view of his interest in Realism and the Novel, it is somewhat strange that he never seems to have read works by George Eliot. Her name appears neither in the non-Marxist works written before 1919, nor in his late aesthetics Die Eigenart des Ästhetischen (1963). Since Lukács and his immediate disciples, working in Budapest, focused on German philosophy and literature, the university of Debrecen became the centre of English studies. The only full-length study of the works of George Eliot was written by Anna Katona (1920-2005), who joined the English Department of that university in 1956. Born in Debrecen, she was interned in 1944, during the German occupation of Hungary. Like many Holocaust survivors, she joined the Communist movement and published essays that represented dogmatic Marxism. Favoured by the political establishment, she was able to visit Britain and the United States with various scholarships. In 1975 she decided not to return to Hungary. Claiming that she had been persecuted in Hungary, she got US citizenship and a visiting position in Charleston (South Carolina).

The title of her book, A valóságábrázolás problémái George Eliot regényeiben (The Issues of the Representation of Reality in the Novels of George Eliot, 1969) reflects the spirit of an age duly forgotten today. The British author is praised as "the faithful chronicler of the reality of the 1850s, 60s, and 70s" ("az 1850-60-70-es évek valóságának hủ krónikása") (Katona, 1969, 198). The homogeneity of the novels is overemphasized: "The novels formulate the same conclusion in different ways" ("Az egymást követő regények ugyanazon tanulság más-más megfogalmazásai”) (Katona, 1969, 157). The charge of pessimism is dismissed and didacticism is treated as inseparable from great art: "In her novels tragedy is not the reflection of a tragic outlook; it serves a didactic purpose. [...] Her characters fall to let others learn from their weaknesses." ("A tragédia nem tragikus világkép tükröződése műveiben, hanem nevelési eszköz. [...] Hősei azért buknak el, hogy mások okuljanak hibáikból.”) (Katona, 1969, 167).

The reason for the great significance of George Eliot's works is that they "tackle almost all the political issues of her age" ("kora szinte valamennyi politikai kérdését érinti”) (Katona, 1969, 49). In this interpretation novels are social documents, verdicts "against a parasitic way of life and its consequences" ("a parazita életmód és következményei ellen"), attacks on "exploitation" ("kizsákmányolás") and representations of "class conflicts" ("osztályellentétek") (Katona, 1969, 119, 38, 14). "No working man is evil in her fiction" ("Nincs egyetlen dolgozó ember gonosztevője sem"), Katona affirms, and she ascribes the value of The Spanish Gipsy to "a humane treatment of Gipsies" ("az emberséges bánásmódot a cigányokra terjeszti ki”), and insists that with her vision of Zionism in her last novel "she anticipated the future" ("elötte járt korának") $(148,174,35)$.

Reiterating the clichés of the so-called Marxist criticism of her age, Anna Katona also expressed her impatience with the class limitations of George Eliot. 
While admitting her belief in "progress", she regretted that she "failed to become a materialist" ("nem jutott el a materializmusig"), was "unable to recognize the historical mission of the working class" ("nem jutott el a munkásosztály történelmi hivatásának felismeréséig"), and "could not arrive at the conclusion that society has to be transformed by revolution" ("nem jutott el a társadalom forradalom útján való megváltoztatásának gondolatáig” (46, 73, 107, 60).

The shortcomings of the book hardly need explanation. Das Kapital, Condition of the Working Class in England, the works of Ernst Fischer, Raymond Williams, and Arnold Kettle, together with a collective work entitled Istorija Anglijskoj Literaturi, published in Moscow in 1956, are used as keys to the understanding of George Eliot's works, and her fiction is treated as an illustration of ideas formulated in her letters and the articles she published in the Westminster Review in the 1850s. The "split between Maryan Evans and her brother is reflected in the fates of Maggie and Tom" ("a Marian Evans és fivére között történt szakadás tükröződik Maggie és Tom sorsában”). "Klesmer is probably Ferenc Liszt, whom she met in Weimar" ("Klesmer valószínúleg Liszt Ferenc, akivel Weimarban találkozott"); "Will Ladislaw may be Lewes and Dorothea the author herself" ("Will Ladislaw valószínűleg Lewes, Dorothea pedig maga az írónő") (Katona, 1969, 133-4, 159). Such details suggest that no distinction is made between autobiography and fiction. The structure of the plot, narrative perspective, temporality, and style are virtually ignored. The overemphasis on ideology leads to the neglect of generic qualities. A distorted vision of The Waste Land as "a representation of the world of the bourgeoisie, in which injustice reigns, giving rise to evil" ("ábrázolta a polgári világot, melyben igazságtalanság uralkodik, ez pedig gonoszságot szül") (Katona, 1969, 140) makes George Eliot the forerunner of the American-born poet. The focus is on the characters evaluated according to the stages in the evolution of human society as suggested by Marxists. Dinah Morris, the Methodist preacher in Adam Bede, for instance, "represents progressive industrial society" ("a progresszívabb ipari közösség képviselője") (Katona, 1969, 82).

All comparisons seem to be questionable. Not realizing that the tradition of starting "in medias res" goes back to Homer, Anna Katona believes that George Eliot is a modern novelist on account of "her departure from chronological narrative" ("egyre kevésbé ragaszkodik a kronológia bevett sorrendjéhez") (Katona, 1969, 190). Echoing the essays written by György Lukács on Realism in the interwar period, she regards such "omniscient authors as Balzac, Dickens, or Tolstoy" ("A mindentudó író, legyen az Balzac, Dickens vagy Tolsztoj") as the greatest novelists, because they "present the extreme complexity of the world as a whole in an epic panorama" ("a világ egészének bonyolult és mérhetetlen sokoldalúságát ábrázolja széles epikai tablóban"), and the assumption is that George Eliot is also one such novelist (Katona, 1969, 9). In her view The Portrait of a Lady is weaker 
than George Eliot's last novel because "it lacks the character of Daniel Deronda" ("Deronda alakjával szegényebb") (Katona, 1969, 121).

In the introduction of her book Anna Katona defined the position of George Eliot between her contemporaries who focused on the surroundings of their characters and the "subjectivist" ("szubjektivista") authors of the 20th century (Katona, 1969, 8). In the sixth and final section she dismissed the "bourgeois" interpretations of George Eliot's works made from the perspective of "the technique of experimental novels", drew a sharp distinction between the vision of the author of Middlemarch and "the chaotic worldview" ("kaotikus világkép") of such "decadent" writers as Joyce and Virginia Woolf, and expressed her hope that the fiction of such authors as Doris Lessing, Angus Wilson, Pamela Hansford Johnson, and others would revive George Eliot's legacy (Katona, 1969, 201, 205).

Whenever citing from the novels discussed in her book, Anna Katona used her own translations, arguing that new Hungarian versions were needed, since the old ones were outmoded. In 1969 only one new version existed, the work of Tivadar Szinnai (1894-1972), a minor novelist, who translated about one-hundred works and made his fortune with adaptations of works by Karl May. In 1976 a new version of Middlemarch appeared. Tibor Bartos (1933-2010) was arguably one of the best translators from English of the later 20th century; his Hungarian versions of works by such authors as Poe, Thackeray, Mark Twain, Jack London, Dos Passos, Henry Miller, William Styron, Tom Wolfe, Ralph Ellison, and Jack Kerouac have won praise from both the critics and the general public. He was a sophisticated interpreter of stylistic nuances who collected synonyms in the course of his working with English texts and summarized the results of this work in two volumes, published in 2002. Despite its considerable merits, his version of Middlemarch is one of the very few Hungarian prose translations that have met with serious criticism. An eminent Hungarian scholar, well-versed in both literary theory and linguistics, pointed out that Bartos "places the narrator in the wrong social context", "creates misleading intertextual connections and connotations", turns "the theoretical aspects of the original into something more concrete", and "demolishes the metaphorical structure" of George Eliot's novel (Bezeczky, 2001, 115, 117, 118). Even less satisfactory is the translation of Adam Bede by Tibor Szobotka (1913-82), novelist, short-story writer, and essayist, since it fails to do justice to the different sociolects used in this novel: uneducated farmers and upper-class characters speak in the same elevated, slightly artificial style.

The new translations were not accompanied by any longer study on George Eliot's works. The seven pages devoted to her in the short book I was commissioned to write on 19th-century British literature for a popular series reflect a shift in values. Having written my Ph. D. dissertation on Virginia Woolf and published my first essay on Henry James, my reading of George Eliot was marked by a bias 
opposed to that of Anna Katona. Although I praised Middlemarch, I saw a serious flaw in Daniel Deronda, and regarded didacticism and the relative absence of poetic language as shortcomings that make her art "inferior to that of Emily Brontë" ("művészete elmarad Emily Brontë teljesítménye mögött" (Szegedy-Maszák, 1982, 276).

After the collapse of totalitarianism in 1989-90, Hungarian translators, critics, and readers turned to works neglected or banned in the so-called Communist decades. The (re)discovery of works unknown to the general public went together with a falling-off in the interpretation of most 19th-century Western novelists. Although feminist criticism made its influence felt in recent decades, relatively little attention was paid to the works of George Eliot. It might be taken as symptomatic that the two-page discussion of her activity in the most recent history of world literature, a collective work of close to 1,000 pages, published in 2005, is a rather low-key appreciation. Written by Ágnes Péter (b. 1941), a professor at Eötvös Loránd University (Budapest) and a specialist of English Romanticism, this summary emphasizes that George Eliot was "the co-editor of the progressive theological and philosophical Westminster Review" ("társszerkesztóje a haladó teológiai és filozófiai folyóiratnak, a Westminster Review-nak"), and her works "anticipate the modernist turn" ("a modernista fordulat előzményeinek tekinthetők") (Pál, 2005, 652). While no oversight occurs in the brief characterization of The Mill on the Floss, Romola, Felix Holt, the Radical, Middlemarch, and Daniel Deronda, the evaluation of George Eliot's activity still echoes the Marxist ideas on Realism.

Market-oriented economy has changed the attitude to literature of the Hungarian public. Recently the George Eliot Collection of the BBC gave an impetus to a Hungarian publishing house to bring out earlier translations of her works and commission new versions. Paradoxically, there seems to be a kind of return to greater freedom in adaptation. The 1966 version of The Mill on the Floss has been rebaptized as Büszkeség és ártatlanság (Pride and Innocence), indicating that in the early 21 st century the more popular Jane Austen can help the promotion of a novel by George Eliot. The title of the new version of Silas Marner is Kései boldogság (Late Happiness), an interpretive decision that may have been inspired by the film industry, suggesting that today publishers believe that the visual media may help them to find potential readers.

It would be difficult, perhaps even impossible to draw any conclusion from the Hungarian reception of George Eliot's works. They won an early recognition in the 19th century. One cannot help but think that the decline in her reputation was at least partly caused by the monograph on her written in a spirit that seems outdated today. It remains to be seen if the impact of visual media can lead to a reappraisal of her work. 


\section{Hungarian Translations}

$\mathrm{AB}$

(1861-62) Bede Ádám, trans. Ferencz Salamon (Pest: Emich Gusztáv).

(1888) Bede Ádám, trans. Ferencz Salamon. 2nd ed. 2 volumes (Budapest: Franklin-Társulat).

(1978) Adam Bede, trans. Tibor Szobotka (Budapest: Európa).

$\mathrm{FH}$

(1874) Felix Holt a Radicalis, trans. Mária Dominkovics (Budapest: Légrády).

$\mathrm{M}$

(1874-75) Middlemarch: Tanulmány a vidéki életböl, trans. József Csukási (Budapest: Athenaeum).

(1976) Middlemarch, trans. Tibor Bartos (Budapest: Európa).

(1998) Middlemarch, trans. Tibor Bartos (Budapest: Esély).

MOF

(1897) A vízi malom, trans. János Váczy (Budapest: Franklin-Társulat).

(1966) A vízimalom, trans. Tivadar Szinnai (Budapest: Európa).

(2010) Büszkeség és ártatlanság, trans. Tivadar Szinnai (Szeged: Lazi).

\section{$\mathrm{R}$}

(1898) Romola, trans. Béla Pataki (Budapest: Franklin-Társulat).

\section{SM}

(1885) A raveloei takács (Silas Marner), trans. Géza Kacziány (Budapest: Franklin-Társulat).

(1898) A raveloei takács (Silas Marner), trans. Géza Kacziány (Budapest: Franklin-Társulat).

(2010) Kései boldogság: Silas Marner története, trans. Judit Gebula (Szeged: Lazi).

\section{Other Works Cited}

A Pallas Nagy Lexikona: Az összes ismeretek enciklopédiája tizenhat kötetben. Vol. VI (1894) (Budapest: Pallas).

A Pallas Nagy Lexikona: Az összes ismeretek enciklopédiája tizenhat kötetben. Vol. X (1895) (Budapest: Pallas).

Babits, Mihály (n. d.) Az európai irodalom története B(udapest: Nyugat).

Babits, Mihály (1978) Az európai irodalom olvasókönyve: Töredék és vázlat (Budapest: Magvető).

Bezeczky, Gábor (2001) 'Structural Metaphors in the English and Hungarian Versions of George Eliot's Middlemarch', Hungarian Studies, Vol. 15, 113-19.

Dominkovics, Mária (1867) Beszélyek (Miskolcz: Fraenkel Bernát biz.).

James, Henry (1984) Literary Criticism: Essays on Literature. American Writers. English Writers (New York: The Library of America).

Katona, Anna (1969) A valóságábrázolás problémái George Eliot regényeiben (Budapest: Akadémiai Kiadó).

Pál, József (ed.) (2005) Világirodalom (Budapest: Akadémiai Kiadó).

Péterfy, Jenő (1903) Összegyüjtött munkái. Vol. III (Budapest: Franklin-Társulat).

Szegedy-Maszák, Mihály (1982) Kubla kán és Pickwick úr: Romantika és realizmus az angol irodalomban (Budapest: Magvetó).

Szerb, Antal (1971) Gondolatok a könyvtárban (Budapest: Magvető).

Szerb, Antal (1980) A világirodalom története 6th ed. (Budapest: Magvető). 